\title{
Pelatihan uji kompetensi keahlian siswa sekolah kejuruan menggunakan metode Participatory Learning and Action (PLA)
}

\author{
Yupi Kuspandi Putra*1, Muhamad Sadali ${ }^{2}$, Fathurrahman ${ }^{3}$, Mahpuz $^{4}$ \\ 1*yupi.putra@gmail.com \\ 1,3 Sistem Informasi, Universitas Hamzanwadi \\ 2,4 Teknik Informatika, Universitas Hamzanwadi
}

\begin{abstract}
Received: 17 November 2020 Accepted: 27 Desember 2020 Online Published: 31 Desember 2020
DOI: 10.29408/ab.v1i2.2772 URL: http://dx.doi.org/10.29408/ab.v1i2.2772
\end{abstract}

\begin{abstract}
Abstrak: Ujian Nasional (UN) kompetensi keahlian pada sekolah menengah kejuruan diselenggarakan rutin setiap tahun oleh pemerintah pusat. Penyelenggaraan UN berfungsi sebagai salah satu penentu faktor kelulusan, persyaratan untuk jenjang pendidikan yang lebih tinggi, dan untuk afirmasi ke daerah. Pemda dapat memanfaatkan hasi UN dalam memetakan capain standar peserta didik, satuan pendidikan, dan wilayah. Tujuan dilaksanakannya pengabdian pada masyarakat ini adalah untuk membantu siswa dalam meningkatkan kesiapan dan keahlian siswa dalam menyelesaikan soal UN kompetensi keahlian dalam bidang multimedia. Sasaran kegiatan ini adalah siswa kelas XII SMK NW Wanasaba yang menjadi mitra utama. Target dan luaran kegiatan ini adalah terbangunnya keterampilan mengerjakan soal-soal UN kompetensi keahlian yang bersifat keahlian keterampilan. Metode yang digunakan adalah Participatory Learning and Action (PLA). Kegiatan ini dilaksanakan dengan memberikan pengetahuan dan ketrampilan secara praktek kepada siswa SMK NW Wanasaba. Dengan adanya pelatihan kompetensi keahlian khususnya dalam bidang multimedia ini, siswa mampu mempersiapkan ujian kompetensi dengan lebih baik.
\end{abstract}

Kata kunci: Kompetensi Keahlian; Multimedia; Participatory Learning and Action; SMK; Ujian Nasional;

\begin{abstract}
National examination for skills competency at vocational high schools is held annually by the central government. The implementation of the national examination is one of the determinants of graduation apart. A national examination is also used for three other things: mapping, selecting to a higher level, and providing assistance or affirmation to the regions. Local governments can also use the national examination to mapping the achievements' standards for students, academic units, and regions. This community service aims to help students increase students' readiness and expertise in solving the national exam for competency skills in the multimedia field. This activity's target is the XII grade students of SMKNW Wanasaba, the main partners. This activity's target and output is the development of skills to work on skills competency National Examination questions, which are skills. The method is Participatory Learning and Action (PLA). This activity was providing practical knowledge and skills to students of SMK NW Wanasaba. This expertise competency training, especially in the multimedia field, can help students prepare for expertise competency exams to get maximum results and improve student competence.
\end{abstract}

Keyword: Expertise Competence; Multimedia; National Examination; Participatory Learning and Action; Vocational High School

\section{PENDAHULUAN}

Dalam dunia pendidikan pemerintah terus meningkatkan mutu pendidikan seiring dengan perkembangan ilmu pengetahuan dan teknologi yang semakin pesat. Sekolah Menengah Kejuruan (SMK) merupakan lembaga formal yang menyelenggarakan pendidikan kejuruan pada jenjang pendidikan menengah sebagai lanjutan dari SMP/MTs atau bentuk lain yang sederajat. Sekolah menengah kejuruan memiliki perbedaan dibanding dengan sekolah 
menengah atas, dimana untuk sekolah menengah kejuruan, siswa dituntut untuk memiliki suatu pengetahuan dan keterampilan sesuai dengan kompetensi keahlian yang di ambil oleh siswa. Keterampilan yang dimaksud adalah keterampilan yang ditunjukkan oleh siswa dengan praktek secara langsung. Pendidikan menengah kejuruan berfungsi untuk mempersiapkan lulusannya yang memiliki ketrampilan memadai untuk menjadi tenaga kerja siap pakai dan trampil (Permendikbud, 2018). Sejalan dengan penelitian yang dilakukan oleh Irwanti \& Sudira (2014) menyatakan bahwa Uji Kompetensi Siswa Keahlian Multimedia di SMK Se-Kota Yogyakarta ditinjau dari aspek context termasuk dalam kategori sangat sesuai $(84,7 \%)$, yaitu relevan dengan kebijakan dan tujuan uji kompetensi, tuntutan pengembangan diri (harapan masyarakat) dan peluang tamatan multimedia di dunia usaha dan industri, serta perkembangan IPTEK.

Salah satu upaya pemerintah dalam meningkatkan pengetahuan dan keterampilan siswa khususnya untuk sekolah menengah kejuruan (SMK) adalah dengan menyelenggarakan ujian kompetensi keahlian yang menjadi penentu bagi kelulusan siswa. Berdasarkan Permendikbud (2018) fungsi dari penilaian hasil belajar adalah untuk (1) mengukur tingkat capaian hasil belajar/kompetensi siswa; (2) mengukur pertumbuhan dan perkembangan siswa; (3) mendiagnosis kesulitan belajar siswa; (4) mengukur efektivitas proses pembelajaran; dan (5) mengukur pencapaian kurikulum. Ujian kompetensi keahlian merupakan salah satu bentuk Ujian Nasional (UN) yang diselenggarakan oleh pemerintah Pusat. UN juga dimanfaatkan untuk tiga hal lainnya, yaitu pemetaan, seleksi ke jenjang yang lebih tinggi dan untuk pemberian bantuan atau afirmasi ke daerah. Selain itu pemerintah daerah dapat memanfaatkan hasil UN untuk melakukan pemetaan pencapaian standar peserta didik, satuan pendidikan maupun wilayah. Seleksi untuk masuk jenjang pendidikan selanjutnya juga menggunakan nilai UN. Dengan demikian nilai UN sangat penting bagi siswa, bagi sekolah nilai UN sebagai dasar pembinaan.

UN diselenggarakan rutin tiap tahun oleh pemerintah pusat. Untuk lebih meningkatkan kompetensi peserta didik di semua Sekolah Menengah Kejuruan secara rutin mengadakan proses UN kompetensi keahlian di sekolah. UN kompetensi keahlian dilakukan dengan menerapkan konsep penguji terdiri dari penguji internal dari sekolah yang bersangkutan dan didampingi oleh penguji eksternal dari instansi/perusahaan yang sesuai dengan kompetensi keahlian yang diujikan. Setiap sekolah pasti menginginkan hasil ujian kompetensi siswanya dapat mencapat target yang diinginkan, dikarenakan ini juga menjadi tolak ukur dan nama baik sekolah di mata dunia usaha/industri atau masyarakat luas. Maka dari itulah pihak sekolah tidak sungkan untuk mencarikan pembimbing khusus untuk membimbing para siswa dalam menyelesaikan suatu kasus/permasalahan yang berhungan dengan ujian kompetensi keahlian. Dalam penelitian Santiyadnya (2015) menemukan bahwa ada tiga hal dampak dari pelaksanaan ujian kometensi keahlian sehingga profesionalisme lulusan sekolah kejuruan rendah, yaitu 1) manajemen resiko yang rendah, 2) pengaruh lingkungan, 3) kurang memiliki bakat dalam kk yang digeluti. Dijelaskan juga dalam penelitian Setiawati \& Sudira (2015) bahwa motivasi berprestasi, disiplin belajar, pengalaman prakerin, sarana dan prasarana, kinerja guru, dan dukungan orang tua memberikan pengaruh yang signifikan terhadap prestasi belajar praktik kejuruan siswa SMK Program Studi Keahlian Teknik Komputer dan Informatika di Kabupaten Sumbawa baik secara parsial maupun simultan.

Di Fakultas Teknik setiap tahunnya selalu rutin menyelenggarakan pelatihan keterampilan untuk persiapan ujian kompetensi, dimana kompetensi keahlian yang sudah dibina 
oleh Fakultas Teknik meliputi Kompetensi Keahlian di bidang Multimedia, Rekayasa Perangkat Lunak, dan Teknik Komputer dan Jaringan, dimana siswa yang menjadi peserta pelatihan ini berasal dari beberapa sekolah mengengah kejuruan yang ada di Kabupaten Lombok Timur. Selain melaksanakan bimbingan kepada siswa SMK dalam mempersiapkan ujian kompetensinya Fakultas Teknik juga secara berkelanjutan selalu diminta oleh sekolahsekolah yang ada di Lombok Timur, baik sekolah negeri maupun sekolah swasta untuk berperan sebagi penguji external, mengingat kompetensi yang dimiliki oleh dosen-dosen di Fakultas Teknik sesuai dengan bidang kompetensi yang di ujikan.

Maka dari itu untuk meningkatkan mutu dalam hal kualitas pengetahuan dan keterampilan pada kesempatan ini program studi Sistem Informasi mengadakan suatu pelatihan kompetensi Keahlian khususnya dalam bidang multimedia, dengan maksud untuk membantu siswa dalam mempersiapkan ujian kompetensi keahlian untuk mendapatkan hasil yang maksimal

\section{METODE PELAKSANAAN}

\section{Waktu dan Lokasi}

Kegiatan pengabdian pada masyarakat ini dilaksanakan mulai tanggal 31 Januari sampai dengan 19 Maret 2020, dan lokasi kegiatan ini diadakan di SMK NW Wanasaba.

\section{Prosedur Pelaksanaan}

PKM ini melalui beberapa tahapan kegiatan yaitu:

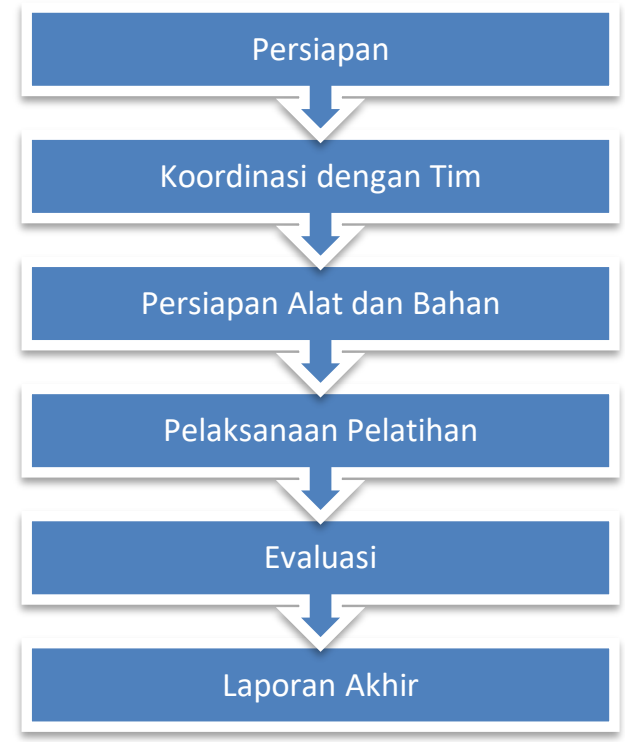

Gambar 1. Tahapan Pengabdian Masyarakat

Pada awal bulan januari mulai melakukan persiapan dengan memilih lokasi atau tempat kegiatan pengabdian yang dijadikan sebagai mitra. Setelah menentukan mitra sekolah kemudian membuat proposal. Pada tahap selanjutnya dengan melakukan koordinasi dengan tim dosen tentang persiapan yang dilakukan sebelumnya. Tim dosen juga harus mempersiapkan alat dan bahan yang dibutuhkan dalam proses kegiatan pengabdian. Pelaksanaan kegiatan pengabdian pada masyarakat ini mulai dilakukan tanggal 31 januari 2020 dengan acara pembukaan bersama tim dosen dengan pihak sekolah. Pelaksanaan rutin kegiatan pengabdian 
ini dilakukan pada siang sampai sore hari. Pada tahap evaluasi tim dosen melakukan koordinasi kembali untuk melihat sejauh mana tingkat keberhasilan dalam pelatihan kegiatan ini dengan mengecek kehadiran siswa, keaktifan siswa di dalam kelas, serta nilai tugas praktik. Kemudian masuk ke tahap akhir yaitu membuat laporan akhir dari semua kegiatan yang telah dilakukan selama pelatihan persiapan uji kompetensi keahlian.

Kegiatan pengabdian pada masyarakat ini dilakukan dengan pendekatan pengembangan pengetahuan dan keterampilan siswa dengan harapan : 1) Mempermudah dalam pengorganisasian, 2) Memperlancar dalam pencapaian tujuan bersama, 3) Meningkatkan kerjasama dengan sekolah mitra yaitu SMK NW Wanasaba. Metode yang digunakan yaitu belajar dan paraktik atau lebih dikenal dengan istilah Participatory Learning and Action (PLA). PLA dipandang lebih komprehensif dengan tahapan dari pembentukan tim, perencanaan kegiatan, pelaksanaan serta monitoring dan evaluasi, sehingga dapat dilaksanakan tanpa harus diimprovisasi maupun modifikasi(Chambers, 1994; Trapsilowati, dkk., 2015). Secara singkat, PLA merupakan metode pemberdayaan masyarakat yang terdiri dari proses belajar tentang suatu topik kemudian setelah itu diikuti aksi atau kegiatan riil yang relevan dengan materi yang sudah dipelajari. Sejalan dengan penelitian pemberdayaan masyarakat di desa Pota Wangka dengan salah satu pendekatan metode PLA yang menjadi salah satu opsi menarik dan mampu diterapkan. PLA yang dikenal juga sebagai learning by doing (belajar langsung) mampu diterapkan oleh LSM You Can melalui pelaksanaan kegiatan sekolah lingkungan (Rachim \& Ginting, 2019). Gagasan mendasar dari PLA adalah komunitas didukung untuk menganalisis situasi mereka sendiri, membuat keputusan tentang cara terbaik untuk mengatasi masalah, dan sebagai hasilnya diberdayakan untuk mengambil tindakan, dimana dalam hal ini komunitas dapat diartikan sebagai peserta didik dengan local knowledge yang dimilikinya (Silmi, 2017). Ditegaskan pula dalam penelitian Komalasari \& Suharjo (2019) yang menyimpulkan bahwa terjadi peningkatan nilai rata-rata pre test dari 60,84 menjadi 77,07 setelah digunakannya metode participatory learning and action dalam pembelajaran. Sehingga kegiatan ini akan menerapkan metode PLA untuk siswa SMK NW Wanasaba kelas XII dalam proses pelatihan peningkatan kompetensi keahlian.

Keikutsertaan peserta didik itu diwujudkan dalam tiga tahapan kegiatan pembelajaran yaitu tahap perencanaan program (program planning), pelaksanaan program (program implementation), dan penilaian (program evaluation) kegiatan pembelajaran (Parastiwi, dkk. 2017). Dengan menggunakan metode PLA ini diharapkan dapat memberikan manfaat bagi siswa peserta pelatihan, diantaranya: 1) pengetahuan dan keterampilan siswa bertambah, 2) dalam menyelesaikan persoalan-persoalan dalam uji kompetensi keahlian siswa menjadi lebih percaya diri, 3) pengetahuan yang didapat selama mengikuti pelatihan dapat digunakan siswa di luar maupun di dalam sekolah, 4) terbentuknya partisipasi dari masyarakat atau pemerintah, sehingga siswa dapat menerapkan pengetahuan yang diperloleh di lembaga-lembaga pemerintahan.

\section{HASIL DAN PEMBAHASAN}

Hasil

Kegiatan pengabdian pada masyarakat ini mulai dilaksanakan pada tanggal 31 Januari 2020 dengan acara pembukaan. 


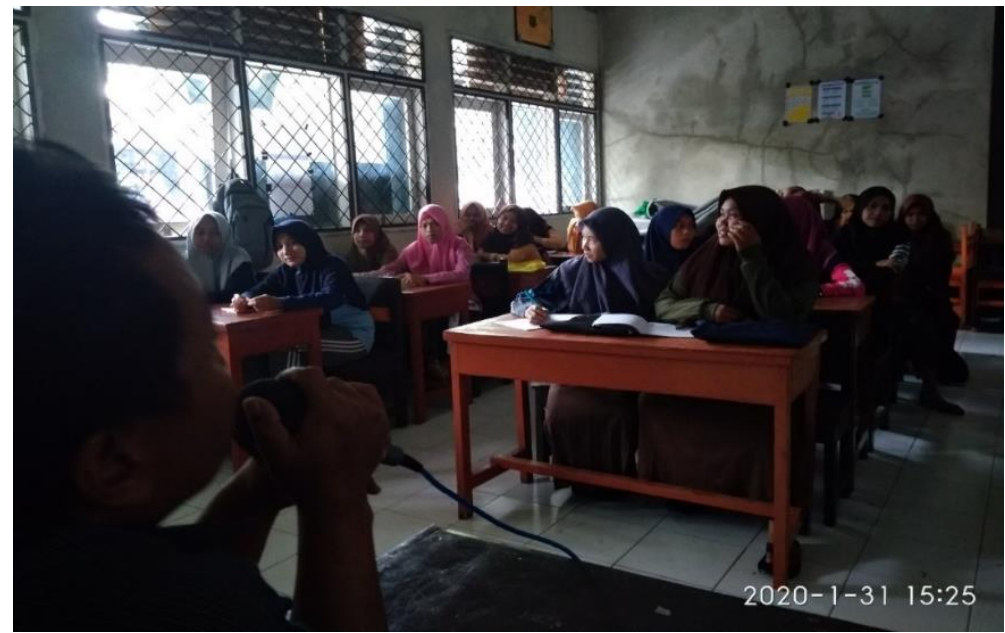

Gambar 2. Acara Pembukaan

Pada tatap muka pertama kali dalam kegiatan pelatihan ini, tim dosen memberikan motivasi kepada siswa dan materi tentang multimedia. Kemudian pada hari-hari berikutnya siswa diberikan praktek yang berkaitan dengan kebutuhan kompetensi keahlian mereka untuk mempersiapkan diri menghadapi ujian kompetensi.

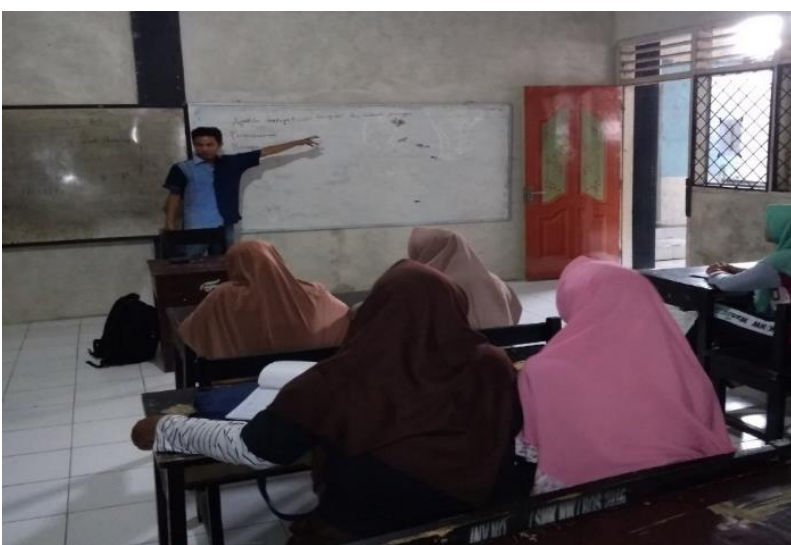

Gambar 3. Pemberian Materi

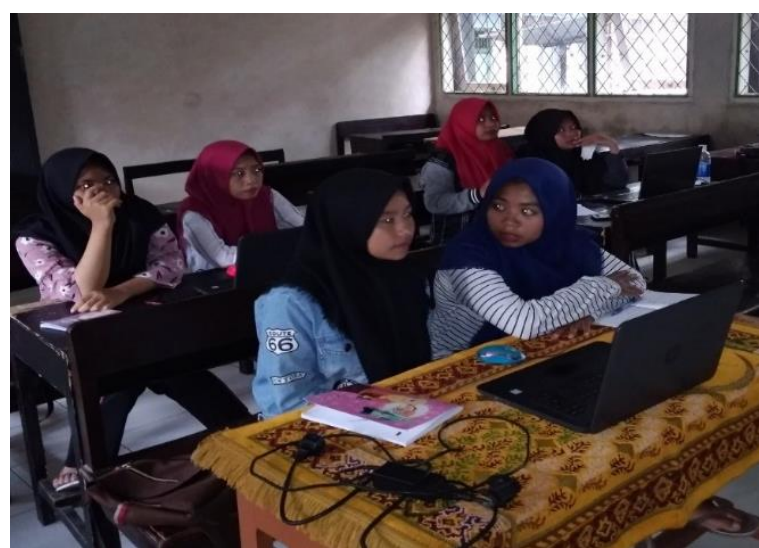

Gambar 4. Kegiatan Praktek

Salah satu cara kegiatan evaluasi dilakukan dengan memberikan tugas praktek kepada siswa secara individu dengan waktu yang sudah ditentukan. Selama kegiatan pelatihan persiapan uji kompetensi keahlian ini, berlangsung dengan baik dan lancar. Sebagian besar siswa sangat antusias dengan adanya pelatihan persiapan uji kompetensi keahlian ini, karena dapat meningkatkan kompetensi keahlian mereka di bidang multimedia. Dalam kegiatan pelatihan ini masih banyak terdapat kekurangan yang harus diperbaiki ataupun dilengkapi pada pelatihanpelatihan berikutnya. Salah satu contohnya yang terdapat pada gambar 4 pada kegiatan praktek siswa masih menggunakan 1 laptop untuk 2 orang siswa. Hal ini menyebabkan tidak efisiennya waktu dalam memberikan materi pada kegiatan praktek.

Berdasarkan hasil nilai tugas praktek siswa dapat disimpulkan bahwa peningkatan kompetensi keahlian siswa belum mengalami peningkatan yang signifikan masih dalam kategori sedang, karena masih terdapat beberapa kekurangan yang nantinya akan diperbaiki pada kegiatan pengabdian selanjutnya. Berikut hasil nilai tugas praktek siswa selama kegiatan persiapan uji kompetensi keahlian. 
Tabel 1. Data Nilai Tugas Praktek

\begin{tabular}{lcccc}
\hline \multirow{2}{*}{\multicolumn{1}{c}{ Deskripsi }} & \multicolumn{4}{c}{ Nilai } \\
\cline { 2 - 5 } & TP1 & TP2 & TP3 & TP4 \\
\hline Skor minimum & 75 & 75 & 80 & 80 \\
\hline Skor maksimum & 80 & 80 & 85 & 85 \\
\hline Rata-rata & 76 & 79 & 83 & 84 \\
\hline Standar deviasi & 2 & 2 & 3 & 2 \\
\hline Kategori & Sedang & Sedang & Sedang & Sedang \\
\hline Ketuntasan & $74 \%$ & $77 \%$ & $80 \%$ & $81 \%$ \\
\hline
\end{tabular}

\section{Pembahasan}

Indikator keberhasilan dalam melakukan pelatihan persiapan uji kompetensi keahlian ini tidak hanya dilihat dari penilaian siswa saja, akan tetapi yang lebih penting adalah kerjasama yang terjalin secara terus menerus antara sekolah mitra dengan pihak universitas hamzanwadi, apalagi keduanya sama-sama di bawah naungan yayasan nahdhatul wathan. Hal tersebut merupakan sebagian dari hasil wawancara dengan pihak sekolah yang menginginkan untuk selalu mendapatkan perhatian dari universitas hamzanwadi. Salah satunya adalah kegiatan pelatihan persiapan uji kompetensi keahlian siswa SMK NW Wanasaba. Berdasarkan hasil wawancara dan evaluasi kegiatan pengabdian ini sangat bermanfaat bagi sekolah mitra terutama bagi siswa kelas XII Multimedia, karena dapat meningkatkan kompetensi keahlian siswa untuk menghadapi ujian kompetensi walaupun pada akhirnya tidak jadi diujikan oleh pemerintah akibat pandemi covid 19. Kegiatan Pengabdian Masyarakat ini melibatkan beberapa unsur diantaranya, 1) Progam Studi Sistem Informasi Fakultas Teknik Universitas Hamzanwadi sebagai pelaksana program, terdiri dari dosen-dosen tetap program studi Sistem Informasi dan Teknik Informatika. 2) Sekolah Mitra yang berasal dari sekolah Swasta yang menjadi mitra utama adalah SMK NW Wanasaba.

\section{SIMPULAN}

Dalam pelaksanaan Pelatihan Uji Kompetensi Keahlian Siswa SMK NW Wanasaba dapat disimpulkan berjalan dengan baik dan lancar sesuai dengan rencana kegiatan yang sudah dibuat walaupun masih terdapat beberapa kekurangan. Dengan adanya pelatihan kompetensi keahlian khususnya dalam bidang multimedia ini, diharapkan dapat membantu siswa dalam mempersiapkan ujian kompetensi keahlian untuk mendapatkan hasil yang maksimal serta dapat meningkatkan kompetensi siswa walaupun pada akhirnya tidak jadi diujikan oleh pemerintah akibat pandemi covid 19.

\section{PERNYATAAN PENULIS}

Artikel ini belum pernah dipublikasikan pada jurnal manapun.

\section{DAFTAR PUSTAKA}

Chambers, R. (1994). The origins and practice of participatory rural appraisal. World development, 22(7), 953-969.

Irwanti, Y. D., \& Sudira, P. (2014). Evaluasi uji kompetensi siswa keahlian multimedia di SMK se-Kota Yogyakarta. Jurnal Pendidikan Vokasi, 4(3). 
Komalasari, R. J., \& Suharjo, M. S. (2019). Penerapan Metode Participatory Learning And Action Pada Materi Penanggulangan Bencana Gempa Bumi Di SMA Negeri 1 Banguntapan Kabupaten Bantul yogyakarta (Doctoral dissertation, Universitas Muhammadiyah Surakarta).

Parastiwi, A., Safitri, H. K., Prasetyo, A., \& Rahmanto, A. N. (2017, October). Penyusunan Strategi Pembelajaran Participatory Learning and Action untuk Meningkatkan Peran Mahasiswa Teknik Elektronika sebagai Agen Energi Photovoltaic. In Prosiding Seminar Nasional Teknologi Elektro Terapan (Vol. 1, No. 01, pp. 169-174).

Peraturan Menteri Pendidikan dan Kebudayaan Nomor 12 tentang Perubahan atas Peraturan Menteri Pendidikan dan Kebudayaan Nomor 22 Tahun 2015 tentang Rencana Strategis Kementrian Pendidikan dan Kebudayaan Tahun 2015-2019. (2018). Jakarta: Menteri Pendidikan dan Kebudayaan.

Peraturan Menteri Pendidikan dan Kebudayaan RI Nomor 34 tentang Standar Nasional Pendidikan SMK/MAK. (2018) Jakarta: Menteri Pendidikan dan Kebudayaan

Pretty, J. N. (1995). A trainer's guide for participatory learning and action. Iied.

Rachim, H. A., \& Ginting, P. A. (2019). Pemberdayaan masyarakat di desa pota wangka labuan bajo melalui program peduli lingkungan (sekolah lingkungan) dengan metode partisipatory learning and action. Prosiding Penelitian dan Pengabdian kepada Masyarakat, 6(1), 46-51.

Santiyadnya, N. (2015, November). Evaluasi Program Pelaksanaan Uji Kompetensi Keahlian Produktif di SMK Negeri 3 Singaraja. In Seminar Nasional Riset Inovatif (Vol. 3 ).

Setiawati, L., \& Sudira, P. (2015). Faktor-faktor yang mempengaruhi prestasi belajar praktik kejuruan siswa SMK program studi keahlian teknik komputer dan informatika. Jurnal Pendidikan Vokasi, 5(3), 325-339.

Silmi, A. F. (2017). Participatory Learning And Action (PLA) di Desa Terpencil: Peran LSM PROVISI Yogyakarta dalam Pemberdayaan Masyarakat di Lubuk Bintialo Sumatra Selatan. Jurnal Pemberdayaan Masyarakat: Media Pemikiran dan Dakwah Pembangunan, 1(1), 83-102.

Trapsilowati, W., Mardihusodo, S. J., Prabandari, Y. S., \& Mardikanto, T. (2015). Pengembangan Metode Pemberdayaan Masyarakat Dalam Pengendalian Vektor Demam Berdarah Dengue Di Kota Semarang Provinsi Jawa Tengah (Developing Community Empowerment for Dengue Hemorrhagic Fever Vector Control in Semarang City, Central Java Province). Buletin Penelitian Sistem Kesehatan, 18(1), 20932. 